УДК 621.391.82

В.С. Наконечний, С.В. Толюпа, I.P. Пархомей, Н.В. Цьопа

\title{
ЕКСПЕРИМЕНТАЛЬНЕ ДОСЛІДЖЕННЯ НАДРОЗРІЗРЮВАЛЬНИХ МЕТОДІВ СПЕКТРАЛЬНОГО АНАЛІЗУ ДЛЯ ЗАДАЧ ПЕЛЕНГАЦІї
}

\begin{abstract}
Анотація: На сучасному етапі розвитку електроніки та у зв'язку з тенденціями до ускладнення електромагнітної обстановки зростає роль радіомоніторингу як засобу для забезпечення іï контролю. Серед основних завдань радіомоніторингу центральне місце займає пеленгація джерел радіовипромінювання, максимально точне визначення їх координат в масштабі часу, близькому до реального. До таких випадків відносяться, навмисні завади, що створюються із різних точок простору певними радіоелектронними засобами. Цим пояснюється актуальність пошуку і дослідження найбільш ефективних алгоритмів обробки інформації для систем радіомоніторингу. 3 цією метою в даній статті представлені результати проведеного експерименту, на основі яких запропоновано найбільш ефективний метод пеленгації джерел радіовипромінювання для систем радіомоніторингу.
\end{abstract}

Ключові слова: цифрова антенна решітка, джерело радіовипромінювання, спектральні функції, радіоелектронний засіб.

\section{Вступ}

В результаті широкого розвитку різноманітних засобів радіозв'язку на сьогоднішній день радіомоніторинг радіоелектронних засобів (РЕЗ) здійснюеться в умовах складної електромагнітної обстановки, великої апріорної невизначеності щодо параметрів радіовипромінювань при їх багатопроменевому розповсюдженні, в умовах часу наближеного до реального, що стимулює розвиток засобів автоматичного радіомоніторингу (APM). До числа АРM належать засоби автоматизованого пеленгування, що вирішують велику кількості задач різноманітних напрямків і $є$ базою для реалізації технічних заходів при протидії несанкціонованому доступу до інфрормації [1].

В задачах радіопеленгування досить часто виникає необхідність шляхом обробки досліджуваного сигналу на кінцевому інтервалі спостереження, визначити кількість джерел випромінювання (ДВ), які формують прийнятий сигнал та максимально точно оцінювати їх кутові координати. При цьому несучі частоти джерел ДВ найчастіше є майже однаковими. До таких випадків відносяться, навмисні завади, що створюються із різних точок простору певними РЕЗ.

Основний метод боротьби з навмисними завадами в радіоелектронних системах (PEC) з цифровими антенними решітками

(c) B.C. Наконечний, С.В. Толюпа, I.P. Пархомей, Н.В. Цьопа, 2015 
(ЦАР) полягає у формуванні провалів діаграми спрямованості в напрямку на джерело завад [2].

В умовах нестаціонарної завадової обстановки вказаний метод формування провалів діаграми спрямованості ЦАР може бути реалізованим, якщо заздалегідь визначити число та кутові координати джерела завад. При цьому найбільш важливими для застосування на практиці е випадки, коли параметри вказаних джерел близькі. В таких випадках традиційні методи виміру та обробки не дозволяють їх розрізнювати, в наслідок обмежень величини розрізнювальної здатності та ефекту маскування спектральних ліній слабких сигналів боковими пелюстками спектральних ліній більш сильних сигналів.

Характерною особливістю процедури визначення числа та кутових координат джерел завад є велике значення співвідношення потужності активних завад до потужності внутрішнього шуму на виході антенної системи, що створюе сприятливі умови для пеленгації ДВ із застосуванням сучасних методів цифррового спектрального аналізу (ЦСА) [3-4].

За останні роки розроблена та досліджена значна кількість методів оцінювання координат ДВ, можливість застосування яких, в реальних системах, грунтуеться на їх обчислювальній складності та вимогах геометрії ЦАР. Незважаючи на значну кількість робіт, присвячених порівняльному аналізу надрозрізнювальних методів ЦСА, необхідно відзначити, що в кожній з них одночасно порівнюються лише кілька методів і то за окремими показниками $[3,5-$ 11]. Отримані часткові результати, іноді суперечать один одному, не дозволяючи надати їм закінчену оцінку. Тому проблема порівняльного аналізу надрозрізнювальних методів ЦСА залишається актуальною і на теперішній час.

Метою даної статті є експериментальне дослідження розрізнювальної здатності методів ЦСА та проведення їх порівняльного аналізу на предмет найбільш ефективного застосування в системах пеленгації ДВ.

\section{Основна частина}

Широкого застосування на практиці набули методи безперервного аналізу: максимальної ентропії Берга; максимальної правдоподібності Кейпона; “тепловий шум”; Борджотті-Лагунаса; багатосигнальної класифрікації MUSIC та ін., при застосуванні яких пеленг на ДВ визначається за максимумом відповідних вихідних функцій.

В роботі [10] перераховані методи поділяються на два класи “повільні” до яких відносяться методи типу Берга, Кейпона, “тепловий шум", та "швидкі", які зазвичай е більш покращеними модифікаціями алгоритмів “повільного" класу: методи MUSIC, RootMUSIC, алгоритм ESPRIT. Проте слід відзначити, що недоліками 
методу MUSIC $е$ необхідність попередньої оцінки розмірності сигнального (або шумового) підпростору, а також велика обчислювальна складність, що є неприйнятним для роботи РЕЗ в режимі часу наближеного до реального. При цьому алгоритми RootMUSIC та ESPRIT можуть бути застосованими лише з певним типом ЦАР [12].

Для дослідження ефективності розрізнювальної здатності були взяті відомі в цифровому спектральному аналізі методи спектральні функції яких мають наступний вид [13]:

1) Максимальна правдоподібність Кейпона (МПК)

$$
\widehat{\mathbf{S}_{1}}(\Omega)=\left(\mathbf{X}^{*}(\Omega) \cdot \widehat{\Psi} \cdot \mathbf{X}(\Omega)\right)^{-1}
$$

2) Тепловий шум (TW)

$$
\widehat{\mathbf{S}_{2}}(\Omega)=\left(\mathbf{X}^{*}(\Omega) \cdot \widetilde{\Psi^{2}} \cdot \mathbf{X}(\Omega)\right)^{-1}
$$

3) Лінійне передбачення Берга (ЛПБ)

$$
\widehat{\mathbf{S}_{3}}(\Omega)=\widehat{\omega}_{m m}\left|\mathbf{e}_{m}^{*} \cdot \widehat{\Psi} \cdot \mathbf{X}(\Omega)\right|^{-2}, m \in 1, M
$$

4) Модифікований алгоритм Кейпона (МАК)

$$
\widehat{\mathbf{S}_{4}}(\Omega)=\widehat{\omega}_{m m} \mathbf{X}^{*}(\Omega) \cdot \widehat{\Psi} \cdot \mathbf{X}(\Omega) \cdot\left|\mathbf{e}_{m}^{*} \cdot \widehat{\mathbf{\Psi}} \cdot \mathbf{X}(\Omega)\right|^{-2}, m \in 1, M
$$

5) Борджотті-Лагунаса (БЛ)

$$
\widehat{\mathbf{S}_{5}}(\Omega)=\mathbf{X}^{*}(\Omega) \cdot \widehat{\Psi} \cdot \mathbf{X}(\Omega)\left(\mathbf{X}^{*}(\Omega) \cdot \widehat{\Psi}^{2} \cdot \mathbf{X}(\Omega)\right)^{-1}
$$

6) Дискретне перетворення Фур’є (ДПФ)

$$
\widehat{\mathbf{S}_{6}}(\Omega)=\mathbf{X}^{*}(\Omega) \cdot \widehat{\Psi} \cdot \mathbf{X}(\Omega) .
$$

Для наведених спектральних функцій використовуються такі позначення: $\mathbf{X}(\Omega)=\left\{\mathbf{x}_{l}(\Omega)\right\}_{l=1}^{\mathrm{M}}-M$ мірний вектор пошуку в напрямку $(\Omega) ; \widehat{\Psi}=\left\{\widehat{\omega}_{i j}\right\}_{i, j=1}^{M}-M \times M$ матриця, що е оцінкою максимальної правдивості кореляційної матриці процесів, які спостерігаються на виході AP; $\widehat{\omega}_{i j}$ - елемент, що знаходиться на перетині $m$-го стовпця та $m$-ї строки матриці; $\mathbf{e}_{m}-m$-й $(m \in 1, M)$ стовпчик одиничної матриці, (*) - знак ермітового сполучення.

Теоретичне дослідження методів (1-6) ретельно проведено в роботі [15], а для їх експериментального дослідження - був розроблений експериментальний вимірювальний комплекс [14].

Умови проведення експериментального дослідження були наступні. В якості двох локальних джерел вторинного випромінювання (ЛДВВ) були взяті дві металеві кулі діаметром 3,5 см роз- 
несені на відстань $\Delta r=30$ см. Відстань від приймальної антени до найближчого ЛДВВ складала 3,85 метри. Максимальна девіація частоти зондувального лінійного частотно-модульованого (ЛЧМ) сигналу при кількості відліків $M$ - мірного вектору рівному 43 , за час спостереження $t_{\mathrm{Cn}}=4$ сс складала приблизно 1 ГГц, що відповідало розрізнювальній здатності за Фур'є $\Delta f_{\Phi}=1 / t_{\mathrm{C \Pi}}=$ $1 / 4 \mathrm{mc}=250,00$ Гц. Максимальне значення величини відношення сигнал/шум складало 35 дБ.

В результаті проведеного експерименту були виміряні значення для побудови графріків залежності $S=f(\Omega)$ для кожного з обраних методів (1-6), які наведенні на рисунку 1 . На графріках (рис. 1) позначено: по осі ординат - амплітуда сигналу, а по осі абсцис - частоти сигналів відбитих від 2-х ЛДВВ.

Аналіз побудованих графріків показав, що при заданих однакових умовах проведення експерименту не всі з досліджуваних методів були спроможні розрізнити два ЛДВВ за критерієм Релея [15]. Найкращу розрізнювальну здатність мав метод ЛПБ. На рисунку 1 б можна чітко спостерігати два максимуми, що відповідають двом розрізненим сигналам відбитих від двох металевих кульок.

При заданих умовах проведення експерименту методи МПК, ТШ та ДПФ мали лише один максимум і не спроможні були здійснювати розрізнювання двох ЛДВВ за критерієм Релея, що демонструють графіки рис. 1 а, рис. 1 в та рис. 1 е відповідно.

На відміну від цього застосування методів БЛ та МАК рис. 1 г та рис. 1 д відповідно, взагалі недоцільно оскільки вони мали випадкові спектральні максимуми і не могли дати адекватної оцінки значення $S=f(\Omega)$ двох ЛДВВ за даних умов проведення експерименту.

На рисунку 2 наведений узагальнений графік нормованих значень $S=f(\Omega)$ для кожної з досліджених спектральних функцій (1-6). Як видно з рисунку 2 спектральні фрункції $(1-3,6)$ мали свої максимуми в діапазоні частот (4500 -5500) Гц, який за дальністю відповідає ділянці простору, де знаходилися два ЛДВВ. Проте лише метод ЛПБ був спроможний розрізнити два ЛДВВ за критеріем Релея.

Програмна частина експериментального вимірювального комплексу дозволяла обирати певне вікно спостереження. Знаючи в якому діапазоні знаходились ЛДВВ можна було більш точно дослідити поводження графіків для спектральних фрункцій $(1-3,6)$ саме в цьому вікні (рисунок 3 ).

\section{Висновки}

Таким чином, однакові умови проведення експерименту та аналіз одержаних результатів залежностей $S=f(\Omega)$ досліджуваних методів пеленгації демонструють суттеву перевагу алгоритму лінійного передбачення Берга у порівнянні з іншими досліджувани- 

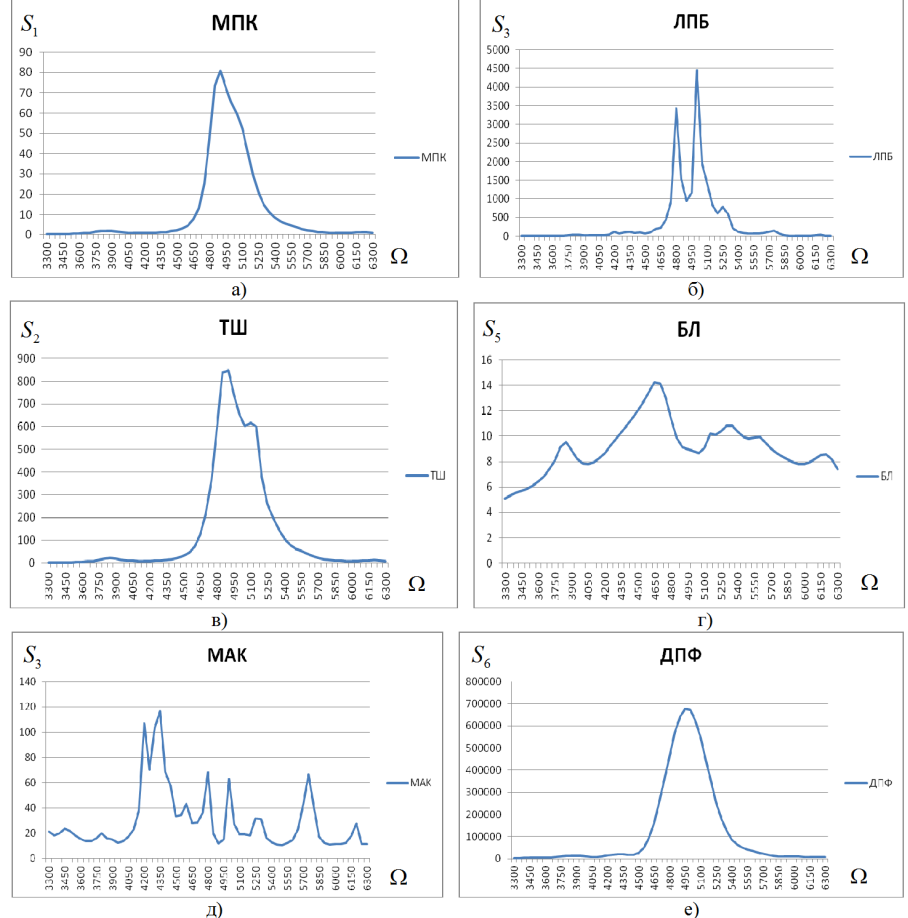

Рис. 1 - Графріки залежності $S=f(\Omega)$ для досліджуваних методів (1-6)

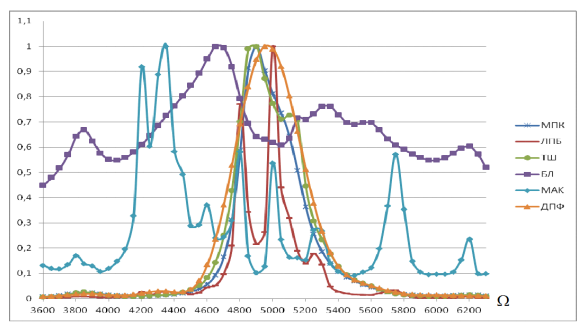

Рис. 2 - Узагальнені нормовані графіки залежності значень $S=$ $f(\Omega)$ досліджуваних методів

ми методами при вирішенні задач максимально точного знаходже- 


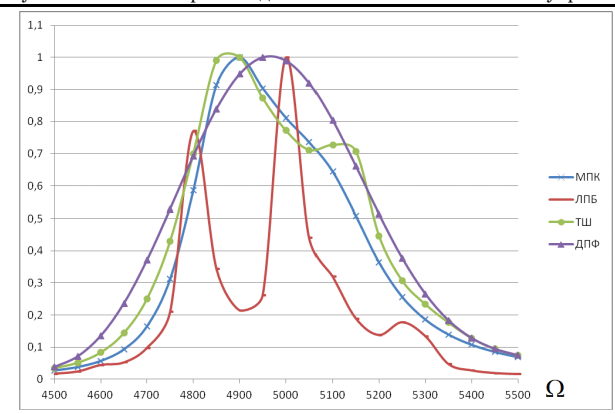

Рис. 3 - Вікно спостереження пропорційне ділянці простору знаходження двох ЛДВВ

ння координат пеленгу локальних джерел випромінювання в умовах часу наближеного до реального.

\section{Список використаних джерел}

1. Рембовский А.М. Радиомониторинг: задачи, методы, средства / Ашихмин А.В., Козьмин В.А.; под ред. А.М. Рембовского. - М.: Горячая линия-Телеком, 2006. - 492 с.

2. Ратынский М.В. Адаптация и сверхразрешение в антенных решетках / Ратынский М.В. - М.: Радио и связь, 2003. - 200 с.

3. Марпл.-мл. С.Л. Цифровой спектральный анализ и его приложения: Пер.с англ. - М.: Мир, 1990. —584 с.

4. Дрогалин В.В. Алгоритмы оценивания угловых координат источников излучений, основанные на методах спектрального анализа. /В.В. Дрогалин и др. // Успехи современной радиоэлектроники. - 1998. - №2. - С.3-17.

5. Джонсон Д.Х. Применение методов спектрального оценивания к задачам определения угловых координат источников излучения.// ТИИЭР, 1982. - Т.70, № 9.

6. Добырн В.В. Эффективность применения сверхразрешающих спектральных оценок в бортовых угломерных фазированных антенных решетках /В.В. Добырн, А.В. Немов // Радиотехника. - 1999. - №9. - С. 65-67.

7. Гершман А.Б. Адаптивное разрешение некоррелированных источников по координате. / А.Б. Гершман, А.Т. Ермолаев, А.Г. Флаксман // Изв. вузов. Радиофизика. - 1988. - №8. - С. 941-946.

8. Леховицкий Д.И. Разновидности сверхразрешающих анализаторов пространственно-временного спектра случайных си- 
гналов на основе обеляющих адаптивных решетчатых фильтров / Д.В. Атаманский, И.Г. Кириллов. Д.И. Леховицкий // Антенны. - 2000. - № 2. - С. 40-54.

9. Мюнье Ж. Делиль Ж.Ю. Пространственный анализ в пассивных локационных системах с помощью адаптивных методов // ТИИЭР. 1987. - Т. 75, № 11. - С. 21-37;

10. Коробков М.А. Корреляционные методы пеленгования источников излучения [Текст] / М. А. Коробков // Молодой ученый. - 2014. - № 13. - С. 55-58.

11. Методи та алгоритми обробки радіолокаційної інформації в багатопозиційних системах зі змінною просторовою конфігурацією / В.А. Дружинін, В.С. Наконечний, С.В. Толюпа та ін. - К.: Логос, 2014. - 251 с.

12. Коробков M.A. Алгоритм UCA Root Rare для задач пеленгования источников радиоизлучения однородной кольцевой антенной решёткой [Текст] / М. А. Коробков // Молодой ученый. 2014. - № 13. - C. 47-54.

13. Леховицкий Д.И. Статистический анализ сверхразрешающих методов пеленгации источников шумовых излучений в АР при конечном объеме обучающей выборки / Д.И.Леховицкий, П.М.Флексер, Д.В. Атаманский, И.Г.Кирилов // Антенны. 2000. - Вып. 2 (45). - С. 23-39.

14. Мордвицев Н.В. Исследование возможности измерений радиолокационных дальностных портретов воздушных целей при использовании современных методов цифрового спектрального анализа / Н.В. Мордвицев, В.С. Наконечний, К.В. Садовый // Контрольно-измерительные приборы и автоматика. - Х.:ФТИ. - 2005. - Вып. май/июнь. - С. 43-47.

15. Финкельштейн М.И. Основы радиолокации. / Финкельштейн М.И. - М.: Радио и связь, 1983. - 536 с.

Отримано 24.10.2015 p. 